\title{
The Discovery of Elijah's Hill and John's Site of the Baptism, East of the Jordan River from the Description of Pilgrims and Travellers
}

\author{
Mohammad Waheeb ${ }^{1}$ \\ ${ }^{1}$ Queen Rania Institute for Tourism \& Cultural Heritage, Hashemite University, Jordan \\ Correspondence: Dr. Mohammad Waheeb, Associate professor, Queen Rania Institute for Tourism \& Cultural \\ Heritage, Hashemite University, Jordan. E-mail: mwaheeb@hu.edu.jo
}

Received: March 13, 2012

doi:10.5539/ass.v8n8p200
Accepted: April 12, 2012 Published: July 1, 2012

URL: http://dx.doi.org/10.5539/ass.v8n8p200

\begin{abstract}
Recent archeological activity in the area of the Jordan Valley, east of the Jordan River in Wadi al-Kharrar, has identified remains dating from the Roman, Byzantine, and early Islamic periods. These remains indicate that the area was inhabited during the time of John the Baptist and Jesus. They also show that monks and hermits lived in the region during the byzantine period and the beginning of early Islamic times. A brief description of the archeological remains is presented here as well as descriptions of pilgrims and travellers from the $4^{\text {th }}$ Century till the present.
\end{abstract}

Keywords: archaeology, excavation, religion, pilgrims, Byzantine, Jordan river

\section{Introduction}

The site called "Bethany beyond the Jordan" (UTM coordinates: 0743979 e/3526317n; elev. -304) is located east of the Jordan River, west of the modern village of al-Kafrayn, and within sight of the town of Jericho west of the river. It is situated at the head of Wadi al-Kharrar and eventually feeds into the Jordan River around $1.800 \mathrm{~km}$ to the west. Due to the springs an oasis dominates the beginning of Wadi al-Kharrar and the site of Tell al-Kharrar. Moreover, thick and green vegetation is characteristic of the entire length of the wadi. As recent archaeological activity shows, the place of Bethany beyond the Jordan was located at or around the natural hill called Elijah's Hill (Tell al-Kharrar).

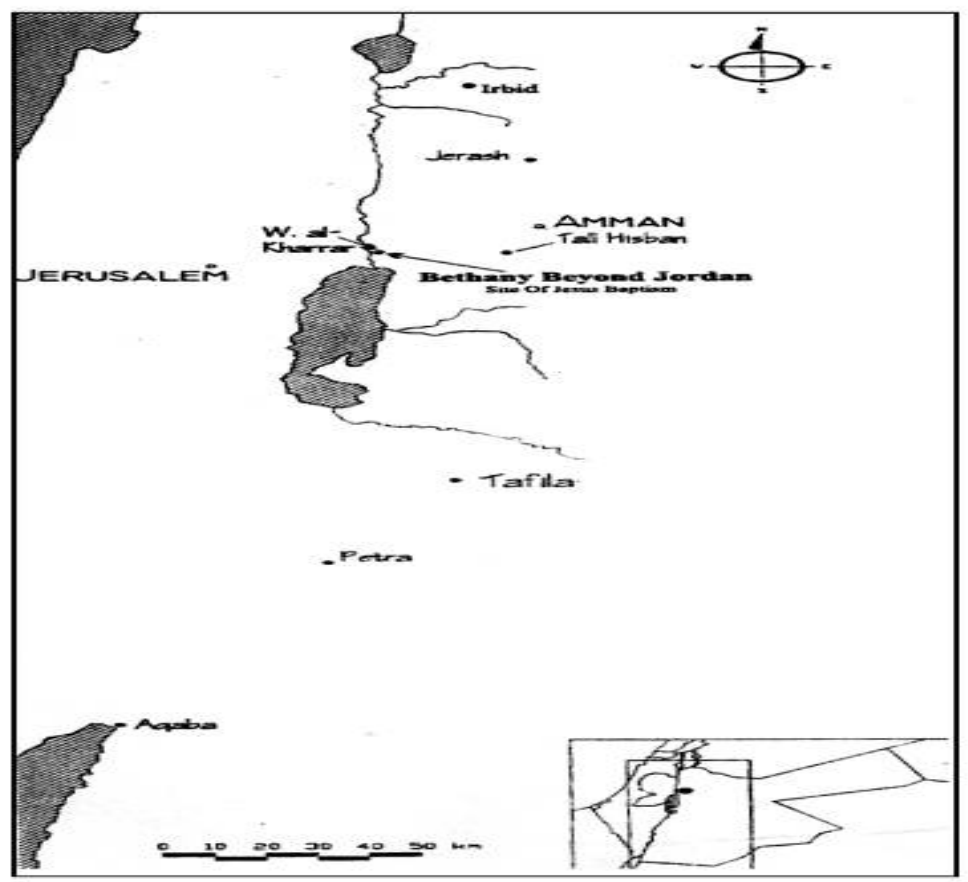

Figure 1. A map of Jordan showing the location of Bethany beyond the Jordan 


\section{Elijah' Hill}

Saint Elijah's hill - Jabal Mar Elias in Arabic - is located at the southeastern end of Wadi al-Kharrar. The hill is associated with the Prophet Elijah's ascension into heaven (2 Kings 2.5-15). Here was the sanctuary located that attracted pilgrims in the medieval period (O.T. Kings.1).

The majority of texts from the second and third centuries propose the reading "Bithynia (i)," that is, "Bethany." There is no general agreement, however, on the meaning of the toponym. Some dictionaries have it meaning "house of dates or figs," others understand it to mean "house of depression or misery." Riesner, on the other hand, sees the place name as derived from Bet "Anniya, "house of the boat" (Ford 1992:704). Such a meaning would place Bethany at one of the ferry crossings/ fords of the river Jordan. This location would fit well with the ministry of John who could easily have been at a place where he could meet people crossing from one side of the river to the other.

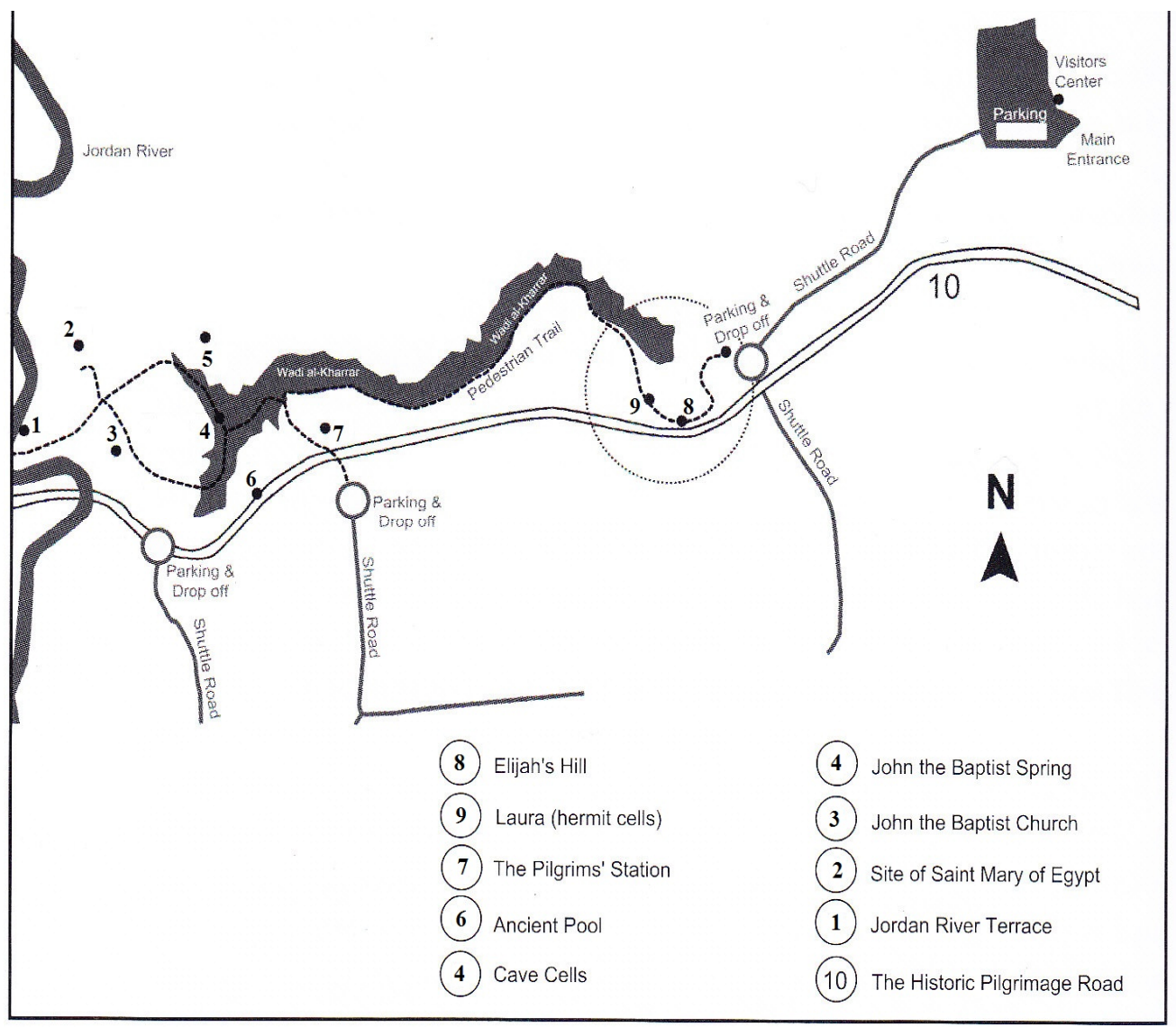

Figure 2. General map showing the discovered sites in Bethany

Origen (ca. $200 \mathrm{AD}$ ), although admitting that almost all the manuscripts read "Bethany", preferred another reading, namely "Bethabara" or "the place of the crossing over". He chose this reading because he could find no place called Bethany in Transjordan. His alternative reading would also place John's baptizing at one of the fords of the Jordan River and thus agrees with that of Riesner (GCS IV.149. see also: Barrios: Bethanie: DBS 1968f; Abel: Geographie, 265).

Eusebius in the Onomasticon and Jerome in the book on the sites and names of places respectively, place Bethabara across the Jordan: (Onomasticom 58, Jerome follows him in his translation). They mention "Bethabara" (Gospel of John 1:28) across the Jordan, where John was baptizing. The place is shown where even now many of the brethren are eager to take a bath. ..."Bethabara across the Jordan, where John baptized unto repentance; whence even today very many of the brethren, that is, of the number of believers, desire to go to be born again there, and are baptized in the life-giving torrent." (Taylor et al. 2003: 38).

The Madaba mosaic map follows Origin and locates Bethabara west of the Jordan (Alliata 1999: 51, 55). Origen's reading, however, is generally dismissed today. 


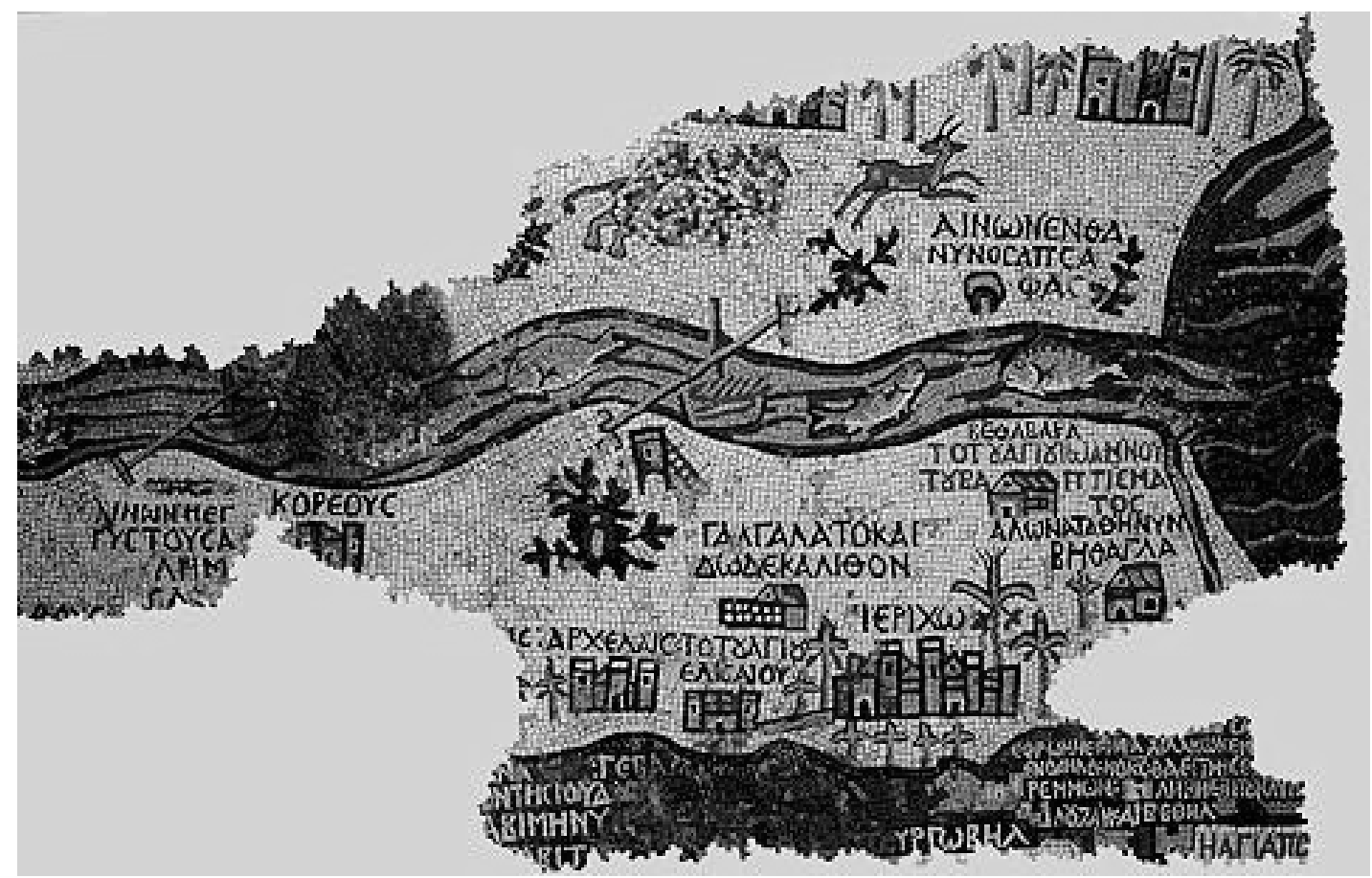

Figure 3. Madaba Mosaic map showing Aenon Sapsaphas on the east bank

\section{Gospel Texts about the Place of John's Baptism}

The Gospel according to John locates one of the places where John the Baptist carried out his ministry as being at Bethany beyond the Jordan (John 1.28). And it is to John that Jesus came from Nazareth in Galilee to be baptized. According to the Gospels of Matthew (4.1-11) and Mark (4.1-13), after his baptism Jesus fasted for forty days and was tempted by Satan in the nearby "wilderness." In the Gospel according to John (1:29), however, there is no temptation of Jesus. Instead, "the next day" that is, the day after the baptism, John saw Jesus coming towards him and declared, "here is the lamb of God who takes away the sins of the world". The following day, when he saw Jesus walk by, John again exclaimed, "see, here is the lamb of God" (1.35). This took place at "Bethany beyond the Jordan" (John 1.28). Only then did Jesus leave for Galilee (John 1.43).

The Gospel texts related to John's baptizing in general and John's baptism of Jesus in particular are considered first. Next, texts related to Elijah and his flight from Ahab as well as his ascension to heaven, are considered. The archeological ruins at Bethany beyond the Jordan, especially Elijah's hill at the eastern end of Wadi al-Kharrar and the area of the Church(es) of John the Baptist on a former course of the Jordan River, are discussed.

A number of Biblical texts (John 1.24-28, 10.40, 3.23, 3.26; Matthew 3.13; Mark 1.9; and Luke3.3) deal with the place of the baptism activities of John the Baptist. In relation to these activities, the place where Jesus was baptized by John also needs to be considered. Finally, a text dealing with Jesus' coming to the place "beyond the Jordan," when persecuted by the religious authorities in Jerusalem, is treated.

\section{John 1.24-28:}

...Now they had been sent from the Pharisees. They asked him, "Why then are you baptizing if you are neither the Messiah, nor Elijah, nor the Prophet?" John answered them, "I baptize with water. Among you stands one whom you do not know, the one who is coming after me; I am not worthy to untie the thong of his sandal. This took place in Bethany beyond the Jordan where John was baptizing".

This text occurs not only at the beginning of the Gospel according to John, but it also deals with the beginning of John the Baptist's ministry. According to the text, the first recorded day of John's activities closes with a reference to "Bethany across the Jordan," where John fulfilled his prophetic mission of announcing the coming of the Messiah. This site is mentioned again in John 10.40, as it is to this place that Jesus goes after the death of the Baptist, while in Jerusalem the opposition against him grows. 


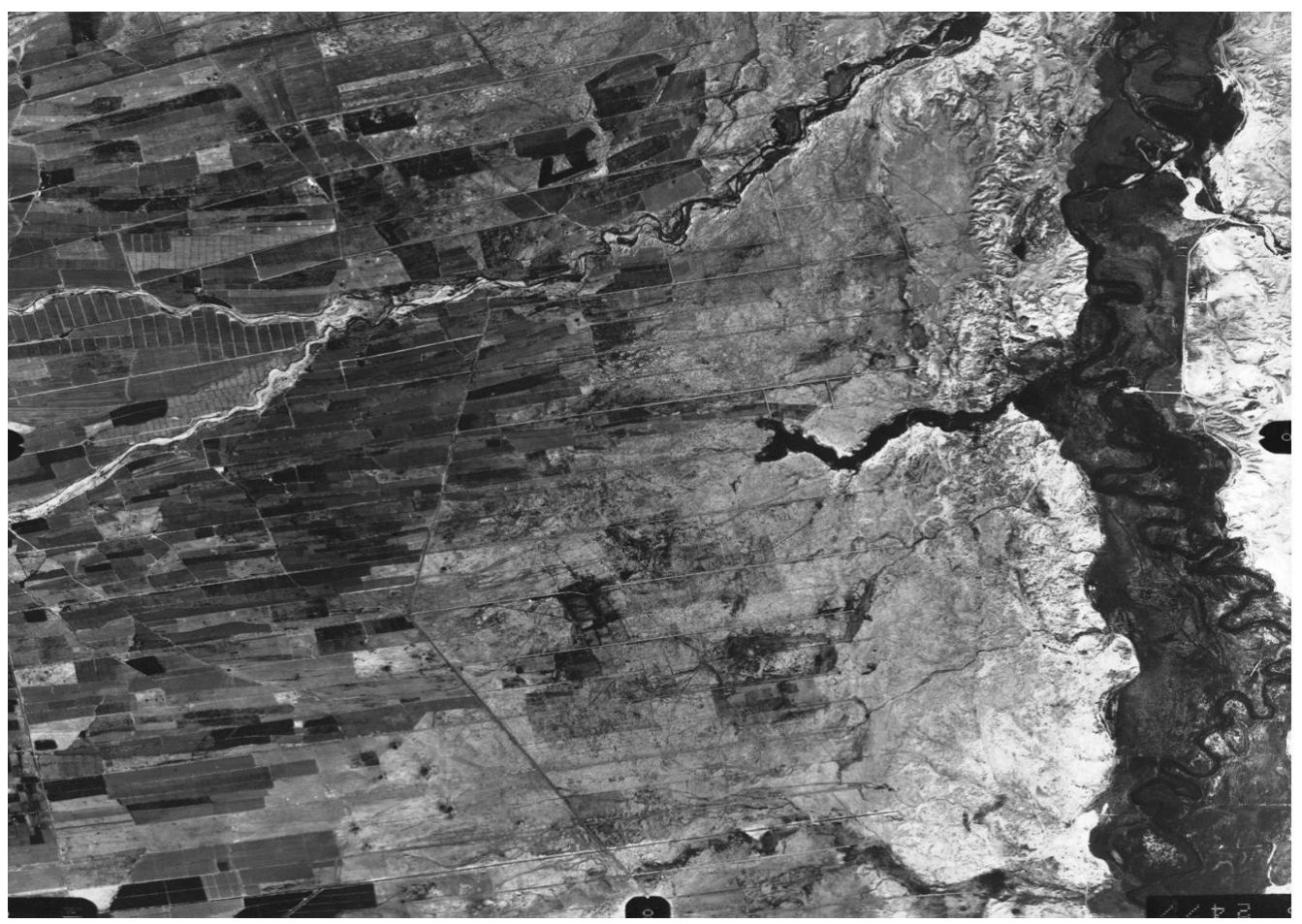

Figure 4. Arial photo for Bethany beyond the Jordan

\section{John 10.40-42}

- He went away again across the Jordan to the place where John had been baptizing earlier and he remained there. Many came to him and they were saying, "John performed no sign, but everything that John said about this man was true." And many believed in him there."

In this text, the place is once again indicated to be "across the Jordan," that is, at Bethany where John had been baptizing. Jesus could possibly have been one of the followers of John the Baptist and conceivably a colony of John the Baptist's disciples could have remained in the area.

Jesus left the hostile land and people of Palestine and crossed to Jordan. There he found the faith that was lacking in his own land. Moreover, while the retirement of Jesus to the region beyond the Jordan had the practical purpose of seeking shelter from the hostility aroused in Jerusalem, it also served the gospel writer's theological purpose: Jesus was not to die by mob violence - he would die only when he was ready to lay down his life.

The Bethany in the text is not the town by the same name near Jerusalem (John 11.18) in which Mary, Martha and their brother Lazarus lived. It is a site "across the Jordan" where recent archeological explorations have uncovered extensive remains that commemorate John's activities and Jesus' presence in the area. Here also Elijah's ascent into heaven is memorialized.

The Gospel according to John provides geographical information about John the Baptist not found in the other three accounts. These geographical details lend credence to the theory that the fourth gospel preserves an independent tradition about john the Baptist. For example, there is a report concerning John the Baptist.

\section{Pilgrims and Travellers Description}

\section{The Bordeaux pilgrim (ca. ad 333) states,}

...It is nine miles from Jericho to the Dead Sea... five miles from there in the Jordan is the place where the Lord was baptized by John, and above the far bank at the same place is the hillock from which Elijah was taken up to heaven (597-98) (Wilkinson 1999:33).

The Bordeaux pilgrim would have approached the river Jordan from the southwest. It does not seem that he crossed the river. He placed John's baptism of Jesus in the Jordan five roman miles $(7.400 \mathrm{~m})$ from the Dead Sea, and he placed the hill from which Elijah was taken up to heaven above the far bank of the Jordan.

Theodosius (ca. ad 518) writes, 
...At the place where my Lord was baptized is a marble column, and on top of it has been set an iron cross. There also is the Church of Saint John the Baptist, which was constructed by the emperor Anastasias (reigned ad 941-518). It stands on great vaults which are high enough for the times when the Jordan is in flood. The monks who reside at this church each receive six shilling a year from the treasury for their livelihood. Where my Lord was baptized there is on the far side of the Jordan the "little hill" called "Hermony", where Saint Elijah was taken up. (Note: Mount Tabor is in Galilee and Mount Hermon - the highest mountain in the region, is on the boarders with Syria and Lebanon). The tomb of Saint Elisha is there at the place where he blessed the spring, and a church has been constructed over the tomb. It is five miles from the place where my Lord was baptized to the point where the Jordan enters the Dead Sea... (Wilkinson 2002:112).

Like The pilgrim of Bordeaux, Theodosius places the baptism of Jesus in the river Jordan five roman miles north of the Dead Sea. A marble column marked the spot. Moreover, Theodosius locates the Church of John the Baptist, built by the emperor Anastasias, on the east bank of the Jordan. The church was built on pillars to protect it at times of flooding. Also like the pilgrim of Bordeaux, Theodosius places the location of the ascension of Elijah on the far side of the Jordan. In addition, Theodosius places a church over the tomb of Elisha at the place where Elisha blessed the spring.

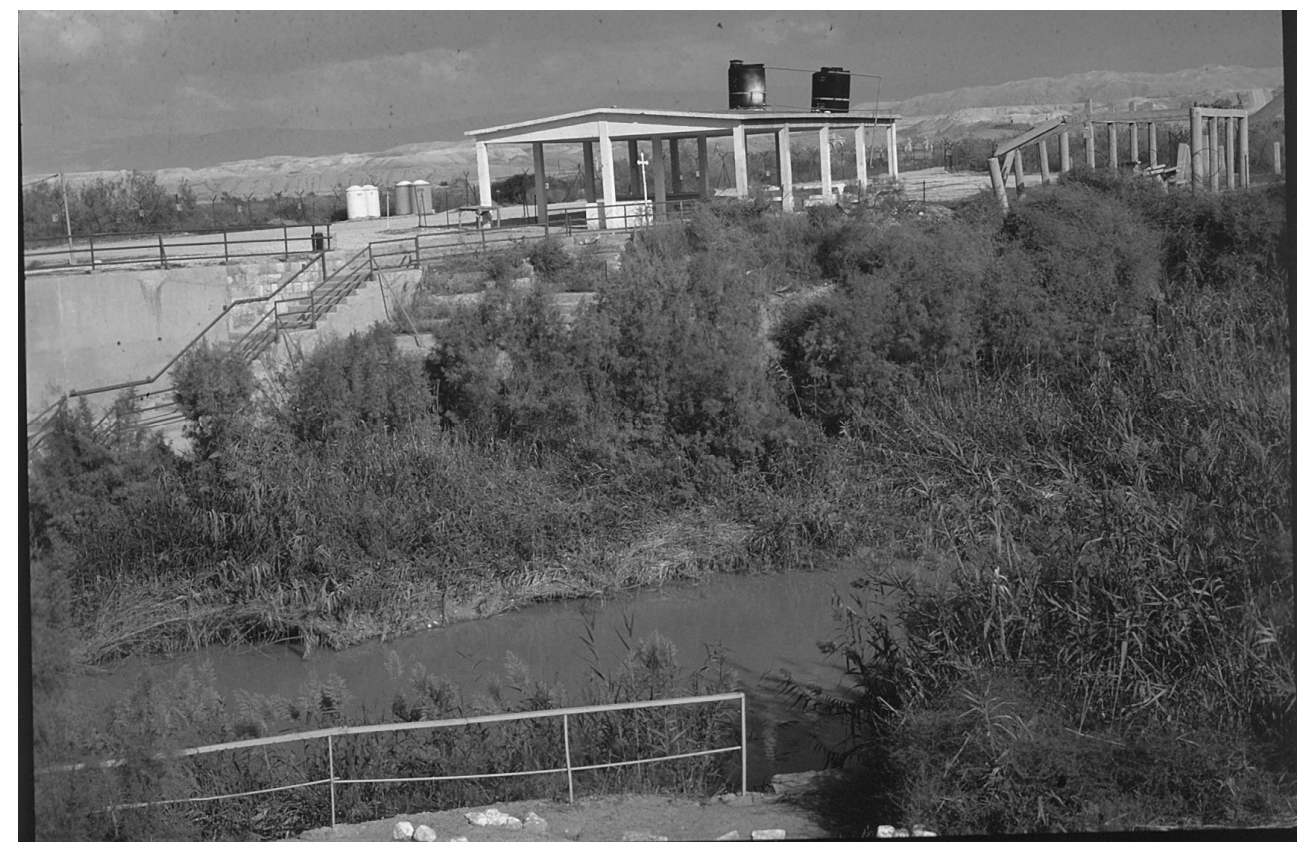

Figure 5. Jordan River surrounding the place of Baptism on the eastern side of Jordan River

\section{Piacenza Pilgrim (ca. ad 570)}

The Piacenza pilgrim has several comments on the location of the site of the baptism and of Elijah's ascension:

.... and from there we arrived at the place where the Lord was baptized. This is the place where the children of Israel made their crossing, and also where the sons of the prophets lost their axe head, and where Elijah was taken up. In that place is the "little hill of Hermony" mentioned in Psalm 133. At the foot of the mountain at seven o'clock in the morning, a cloud forms over the river, and it arrives over Jerusalem at sunrise, about the basilica on Sion and the basilica at Christ's tomb, the basilica of Saint Mary and Saint Sophia (once the Praetorium where Christ's case was heard). Above these places the dew comes down like showers, and sick people collect it. In the hospices all the dishes are cooked in it, and in the places where this dew falls many diseases are cured. For this is the dew of which the psalmist sings, "like as the dew of Hermony ("Hermon") which fell upon the hill of Sion." In that part of the Jordan is the spring where Saint John used to baptize, which is two miles from the Jordan, and Elijah was in that valley when the raven brought him bread and meat. The whole valley is full of hermits". (9; Wilkinson 1999:135).

"I kept epiphany at the Jordan, and on that night special miracles take place at the spot where the Lord was baptized. There is an obelisk there surrounded by a screen and in the water where the river turned back in its bed, stands a wooden cross. On both banks there are marble steps leading down to the water." (11; Wilkinson 1999:136). 
"On the bank of the Jordan there is a cave in which are cells for seven virgins.... We went in with great reverence to pray there, but we did not see the face of a single one of them. It is said that the cloth is there which the Lord wore on his face. By the Jordan, not far from where the Lord was baptized, is the very large monastery of Saint John, which has two guest-houses...” (12; Wilkinson 1999:137).

The Piacenza pilgrim came to the place where the Lord was baptized. An obelisk, surrounded by screens, marks the spot. He agrees with Theodosius on this point. In addition, a wooden cross indicates the spot where the river turned back in its bed and the children of Israel made their crossing (Joshua 3.1-17). The anonymous pilgrim notes that on both banks there are marble steps leading down to the water. The monastery of Saint John is nearby, along with its hostel. He also identifies it as the place where Elijah was taken up to heaven (2 Kings 2.11). He refers to the latter as the "little hill of Hermony" mentioned in Psalm 133.3. Moreover, the pilgrim of Piacenza refers to the spring, two miles from Jordan, where John used to baptize, and where Elijah was fed by ravens (1 Kings 17.6). This description would fit Wadi al-Kharrar.

\section{The Georgian Calendar}

The Georgian calendar of the Church of Jerusalem (sixth - seventh century) recorded three liturgical meetings by the Jordan River on the feast of the Epiphany:

1) on the fourth of January, on the eve of the Feast of the Baptism, the assembly meets on the other side of the Jordan;

2) on the fifth of January, the Vigil of the Epiphany, it gathers on the banks of the river; and

3 ) on the sixth of January, a solemn assembly is held at the Jordan, to commemorate the baptism in the church of Saint John the Baptist, built inside the monastery (Piccirillo 2006a: 44i).

\section{John Moschus (ca. ad 615)}

John Moschus relates a tale about the area where John the Baptist lived.

...There was an elder living in the monastery of Abba Eustorgios whom the saintly Archbishop of Jerusalem wanted to appoint Higoumen of the monastery [the monk in charge of a monastery]. $<$ The candidate $>$ however would not agree and said: "I prefer prayer on mount Sinai." The Archbishop urged him first to become $<$ Higoumen $>$ and then to depart $<$ for the mountain $>$ but the elder would not be persuaded. So $<$ the Archbishop $>$ gave him leave of absence, charging him to accept the office of Higoumen on his return. $<$ The elder $>$ bid the Archbishop farewell and set out on the journey to Mount Sinai, taking his own disciple with him. They crossed the river Jordan but before they reached even the first mile-post the elder began to shiver with fever. As he was unable to walk, they found a small cave and went into it so that the elder could rest. He stayed in the cave for three days, scarcely able to move and burning with fever. Then, whilst he was sleeping, he saw a figure who said to him: "Tell me, elder, where do you want to go"? He replied: "To Mount Sinai. "The vision then said him: "Please, I beg of you, do not go there", but as he could not prevail upon the elder, he withdrew from him. Now the fever attacked the elder more violently. Again, the following night, the same figure with the same appearance came to him and said: "Why do you insist on suffering like this, good elder? Listen to me and do not go there." The elder asked him: "who then are you?" The vision replied: "I am John the Baptist and that is why I say to you: do not go there. For this little cave is greater than Mount Sinai. Many times did our Lord Jesus Christ come in here to visit me. Give me your word that you will stay here and I will give you back your health." The elder accepted this with joy and gave his solemn word that he would remain in the cave. He was instantly restored to health and stayed there for the rest of his life. He made the cave into a church and gathered a brotherhood together there; the place is called Sapsas. Close by it and to the left is the Wadi Chorath (Cherith) to which Elijah the Tishbite was sent during the drought; it faces the Jordan (Moschus 1992:4-5).

The elderly monk was going from Jerusalem to Mount Sinai by means of Transjordan and the road that went south to Ayla on the Red Sea / Gulf of Aqaba. He crossed over the Jordan River and was soon struck by a fever before going more than one roman mile $(1.480 \mathrm{~m})$. The apparition of John the Baptist took place at Sapsas (Sapsaphas), a place located on the Madaba mosaic map immediately to the east of the Jordan River ("Aenon, where now is Sapsaphas" (Alliata 1999:51, 54). The story locates both the place where Jesus came to visit John and to which Elijah fled in the area of what is now Wadi al-Kharrar. The site became a place for a brotherhood of monks on Jordan's east bank. Both the pilgrim of Piacenza and John Moschus distinguish between the place where the Baptism of Jesus was commemorated on the banks of the Jordan River and the place near the spring of Aenon / Sapsaphas to the east, where Jesus and John stayed. The same distinction is made on the Madaba mosaic map: Bethabara on the river and Aenon / Sapsaphas beyond the Jordan. 


\section{Arculf (seventh century) states:}

The holy, venerable spot at which the Lord was baptized by John is permanently covered by the water of the Jordan River, and Arculf who reached the place, and has swam across the river both ways, says that a tall wooden cross has been set up on that holy place.

...The position of this cross where, as we have said, the Lord was baptized, is on the near side of the river bed. A strong man using a sling can throw a stone form there to the far bank on the Arabian side. Form this cross a stone causeway supported on arches stretches to the river bank, and people approaching the cross go down a ramp and return up it to reach the bank. Right at the river's edge stands a small rectangular church which was built, so it is said, at the place where the Lord's clothes were placed. The vaults make it usable, since the water, which comes in from all sides, is underneath it. It has a tiled roof. This remarkable church is supported, as we have said, by arches and vaults, and stands in the lower part of the valley through which the Jordan flows. But in the upper part there is a great monastery for monks, which has been built on the brow of a small hill nearby, overlooking the church. There is also a church built there in honor of Saint John the Baptist which, together with the monastery, is enclosed in a single masonry wall" (Wilkinson 2002:190-91).

Arculf's account places the baptism of Jesus within the river itself. A tall wooden cross marks the spot. Form this cross a causeway stretches to the east bank, where a ramp leads upward. Arculf recounts that a church on this bank (the eastern one) "right at the river's edge" marks the spot where Jesus placed his clothes at the time of his baptism. It is located in the lower part of the valley. Beyond, there is a monastery that overlooks the church. At the monastery, there is a church built to honor John the Baptist; together with the monastery it is enclosed in a single masonry wall. Much of this is similar to the account of Theodosius.

\section{Epiphanius the monk}

Epiphanius (last half of the seventh- first half of the eighth century) writes:

....and about three miles beyond the Jordan, a cave in which lived the Forerunner. There too is the bed on which he slept, a natural shelf in the rock of the cave, and a small chamber. Inside the cave is the sound of water and in the room is a spring in which Holy John the Forerunner used to baptize (Wilkinson 2002: 213-14).

Epiphanius places the cave in which John the Baptist lived about three miles from the Jordan. It is also here that he places John's baptizing activities.

\section{Willibald (first half of eighth century)}

He relates ...the monastery of St. John the Baptist, where there are about twenty monks. One night they remained there, and then went on above a mile to the Jordan, where our Lord was baptized... (Waheeb: 2005).

Willibald knew of a monastery dedicated to Saint John the Baptist. He indicates, furthermore, that the distance from this monastery to the Jordan, where Jesus was baptized, is about 1,480 meters.

\section{Abbot Daniel (AD 1106-1107) states:}

Not far away from the river, a distance of two arrow throws, is the place where Prophet Elijah was taken into heaven in a chariot of fire. There is also the grotto of Saint John the Baptist. A beautiful torrent full of water flows over the stones towards the Jordan. The water is very cold and has a very good taste; it is the water that John drank while he lived in the holy grotto. (pilgrimage of the Russian abbot Daniel to the Holy Land 33; Wilson 1895:29).

Abbot Daniel places the site of the ascension of Elijah and the grotto of John the Baptist at some distance from the Jordan. At this location water flows towards the Jordan. The abbot appears to be describing Wadi al-Kharrar.

After the period of the crusades, the memory of the place of the baptism was not lost. For example, Grethenios (ad 1400) writes: “...it is said that beyond the Jordan one can find the grotto of Saint John; it is the place where he baptized the people. We did not go there for fear of the Arabs" (Piccirillo b1999b: 220).

From all the above it is evident that from the sixth century onwards, the monastery of Saint John on the east side of the Jordan river remained the location where people placed the sanctuary of the baptism. Moreover, the texts tell of the existence of a second church on the eastern bank of the river in front of the Monastery of Saint John.

During the crusades, the Jordan River became a frontier line between the Latin kingdom of Jerusalem and the Sultanate of Damascus. This political situation resulted in the abandonment of the sanctuaries on the east bank of 
the river and moving the ceremonies to its west bank. This situation has continued until the present (Piccirillo 2006: 441).

The above texts are witness to a constant recognition of the place of John the Baptist's activities "beyond the Jordan." The fourth gospel consistently emphasizes that his initial activity was "across the Jordan" (3:26; 10:40) and furnishes the further specification that the precise place was called "Bethany across (or beyond) the Jordan" (John 1.28). This is now supported by the recent archaeological excavations at Elijah's hill, the Wadi al-Kharrar, and along the east bank of the Jordan where the wadi enters it.

\section{Bethany beyond the Jordan}

Archaeological activities, which started in 1899 with explorations in the area of the estuary of Wadi al-Kharrar, identified the remains of a church on the east bank of the Jordan.

The first short account of the monticulus of Elias which mentions that it was about eighty-six yards long and forty-three yards broad, was written by L. Federlin in 1902. On top he found many weather-beaten lumps of freestone which apparently had belonged to various buildings. He could not trace the plan of these, but one seemed to him to have stood about sixteen yards square (La Terre Sainte 1902, 154f).

In 1931, D. Buzy made a more thorough examination of the hill and wadi. He, too, used only his eyes, but vowed to begin excavations without delay. Unfortunately he never carried out his intention. He no longer found any hewn stones on the mount of Elias. The local people had made off with them. When the sand is removed, however, "traces of the walls of houses appear everywhere". Ceramics and tesserae show that the hill was inhabited in Byzantine times. Then he moved back along the course of the wadi, and thought he found traces there of fifty, or perhaps even a hundred houses (Recherches de Science Religieuse 21, 1931,458). A year later, Abel saw upon the hill "very clear traces of ancient foundations". He too, discovered weathered sandstone and a few pieces of ceramics down the wadi, but none earlier than Byzantine (RB 4 (1932) 238f).

Wilken describes Palestine as it was under British mandate before the second world-war. He maintains that, on the slopes of the Mount of Elias there were pieces of pottery dating from the time of Christ, and near them, five rock-graves with contents belonging to the same period (Note 1).

This would have provided Bethany with an archaeological basis; but in the long time which elapsed between visiting the site and writing down the facts, many things became confused in his mind.

The remains he describes were located in front of the remnants of a monastery. In addition, the remains of hermit's cells near the source of the wadi at Jabal Mar Elias/ Saint Elijah's hill were identified. The two sites were visited until 1947 when, due to the political situation in the area, visits had to be suspended. The six-day war of 1967 resulted in this area of the river Jordan becoming a fortified zone and thus off limits to civilians. With the peace treaty between Jordan and Israel in 1994, the area was once again opened up for explorations.

Field excavations were started during the summer of 1996 and revealed the presence of several architectural remains, as follow:

\section{Rhetorius monastery:}

The byzantine monastery called Rhetorius monastery (fifth- sixth centuries) that was uncovered is located on Saint Elijah's hill at the western edge of Wadi al-Kharrar. It connects with the place where Jesus was baptized, a distance of ca. $1.5 \mathrm{~km}$ to the west. It is on the pilgrimage route from Jerusalem to mount Nebo through Bethany beyond the Jordan.

The name of the monastery comes from an inscription found in the apse of its northern church.

The inscription reads: "By the help of the grace of Christ our lord. The whole monastery was constructed in the time of Rhetorius, the most God-beloved presbyter and abbot. May God the Savior give him mercy". (Waheeb 1998:636).

The monastery is comprised of several churches and other buildings within an enclosure - a wall to protect from erosion rather than to serve a defensive function. An entrance in the northwestern wall leads to the living quarters of the monks. The monastery and its churches were probably built to commemorate John the Baptist and Elijah. Because of the spring, the monastery had a good source of water. In the mid-to-late Ottoman period $\left(16^{\text {th }}\right.$ $18^{\text {th }}$ centuries AD), Greek orthodox monks established another monastery at the site, which consisted of structures for worship, residence, and accommodations for visiting pilgrims. 


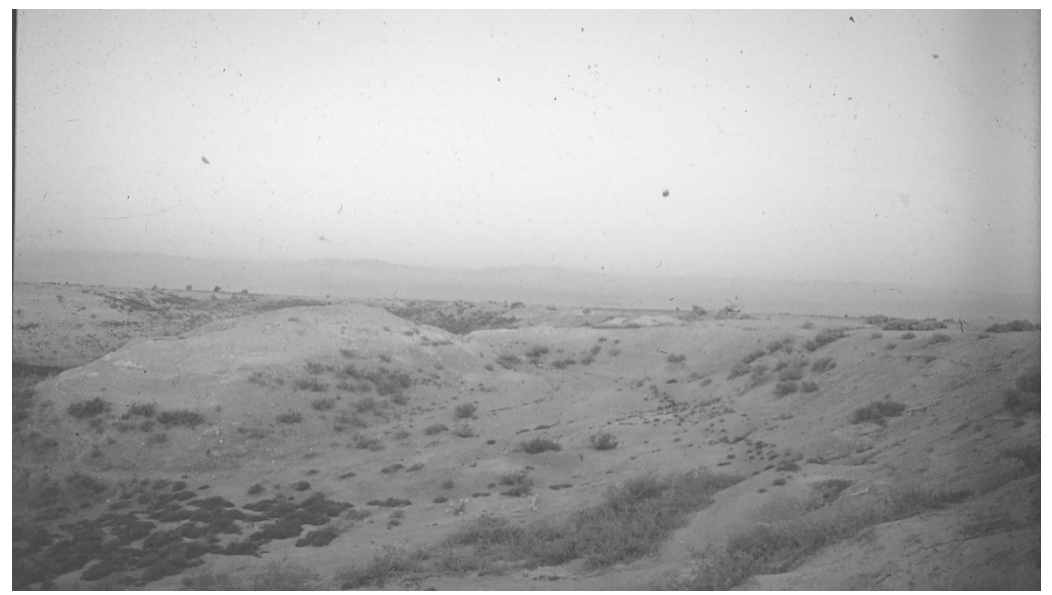

Figure 6. Elijah's Hill before excavation works (Waheeb 1996)

\section{Northern church:}

The Northern church of the Rhetorius monastery has a typical byzantine design of an altar area separated from the nave - the central part of the church - by a chancel screen. A colored mosaic, which included cross marks and geometric designs within a frame, covered the floor. The inscription cited above comes from this church. The entrances to the church are in its northern and western walls.

\section{Western church/ cave church:}

The Western church of the monastery is comprised of two parts. One part consists of a semi-circular apse cut into the natural rock. There are lamp niches carved into southern and eastern walls. A chancel screen separates this part of the church from the second part, namely the nave consisting of the main and two side aisles, separated by columns. Four column bases, built of well-dressed, square-cut sandstone blocks, are still in place.

\section{The pools:}

Three pools are located on Elijah's hill. (Waheeb 1998; 2001a and b), the excavator, dates the first one, located on the hill's lower southern slope, to the third-fourth centuries AD. The pool, rectangular in shape, had an inner staircase on the eastern side, with four steps extending along the full width of the pool. It is clear that pilgrims would descend into the pool to be baptized. The other two pools, dating from the late Roman period, are located on the top of the northern edge of the hill, overlooking the northern church. They are almost square. Large ashlar blocks were added to the southwestern corner of the northwestern pool at a later period; they could possibly have formed a staircase to go down into the pool. Excavations under the damaged floor of the northeastern pool revealed a well or deep cistern, dating from the early Roman to late Byzantine periods. It is built of well- cut sandstone ashlars. The pools received their water supply through channels carried over arches.

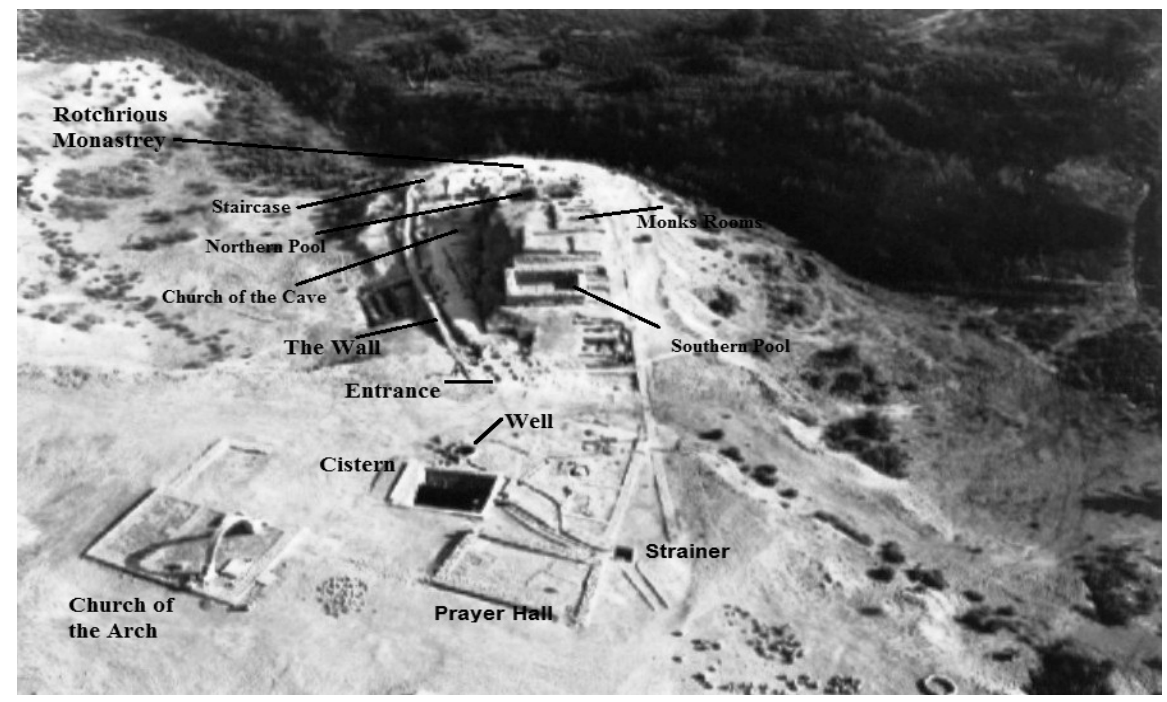

Figure 7. Elijah's Hill after excavations showing the recovered architectural remains 


\section{Wadi al-Kharrar}

\section{Prayer hall}

What is believed to be a Prayer Hall is located down the slope of Elijah's hill and near its southern corner. It is a rectangular structure, measuring $10.70 \times 7.40 \mathrm{~m}$, built of undressed field stones. A plain white mosaic pavement covered its floor, while the roof was probably made of wood and reeds. The excavator thinks that based on its construction and location it may have functioned as a prayer hall or chapel. It could date from before the fourth century AD (Mikhjian 2005: 407). If so, it might be the earliest worship facility at the site.

\section{Water system:}

A water system, consisting of a cistern and settling basins, is located near the Prayer Hall and the small chapel called the Church of John Paul II. It was dug out of the natural marl rock and is the largest reservoir discovered at the site. Its inner walls are built of well-cut sandstone ashlars covered by a smooth layer of plaster to prevent seepage. The excavator thinks that the system was roofed by a vault system. He dates it to the fifth-sixth century's AD.

The excavators have identified ceramic pipes $300 \mathrm{~m}$ to the southeast of the main settlement. These pipes would have brought water to the site from the nearby wadis that flow into the valley from the foothills to the east.

\section{The Church of John Paul II:}

A rectangular church or chapel, measuring $13.65 \times 9.45 \mathrm{~m}$, is located on the saddle of land south of Saint Elijah's hill. The excavators think that incoming pilgrims used it for prayer and worship. The church had a mosaic floor with cross decorations and arches supporting the roof. One of these arches has been reconstructed. The structure was probably built during the fifth-sixth centuries AD. It is presently called the Church of John Paul II to commemorate the pope's visited to and blessing of the site on March 21.2000.

\section{Laura:}

Not far from Tell al-Kharrar, at a distance of ca. 300m to the west on the southern edge of Wadi al-Kharrar, the excavators uncovered some architectural remains. These consist of small structures with foundations built from local field stones and upper courses built from mud bricks; with roofs constructed from wooden beams. Monks would have used these structures as their living and prayer quarters and for offering necessary services to the pilgrims visiting the site. The excavators think that these structures were part of a Laura, or a group of individual hermit cells, associated with the monastery.

\section{The pilgrims' station:}

It appears that the pilgrims station was built during the fifth- sixth centuries $\mathrm{AD}$, between the Jordan River and Tell al-Kharrar. It consisted of a number of rooms around an open courtyard, served by an adjacent water pool.

It is thought that from the fourth century onwards, Christian pilgrims visited the region east of the Jordan River on their way from Jerusalem to mount Nebo. From the pilgrims station, they would have visited the Christian facilities associated with Elijah, John the Baptist and Jesus along the Wadi al-Kharrar, which at that time would have been known as Sapsaphas, a name that appears on the Madaba mosaic map. From here, pilgrims would have continued on to Livias (Tell ar-Ramah) and then on to mount Nebo.

\section{Ancient pool:}

The large pool in the lower area of the site, uncovered just east of the Jordan river, measures over $25 \times 10 \mathrm{~m}$ and was constructed of large stones covered with plaster. It may have been used for group baptisms in the byzantine period, since it could accommodate 300 persons. A canal directed water into the pool form a nearby spring to the north. Another canal carried water out of the pool's southern wall. On the basis of the materials recovered form the pool, the excavator dates the structure to the fifth- sixth centuries.

\section{John the Baptist spring:}

Travelers and historians describe this spring as flowing from a point near Saint Elijah's hill. Pilgrims recount that water from the spring was used for drinking and for baptisms. Several structures and pools were built along the route of the fresh water. Ancient writers refer to this location as Aenon.

\section{Cave cells:}

Surveyors in the area found two caves just to the north of the John the Baptist spring. The caves were dug into the upper layers of the lisan marl cliffs and would have been used by monks as dwellings (cells). They have 
prayer niches carved into their eastern walls. The monks would have gained access to the caves by using ropes or ladders. These caves could have been part of the Laura described previously.

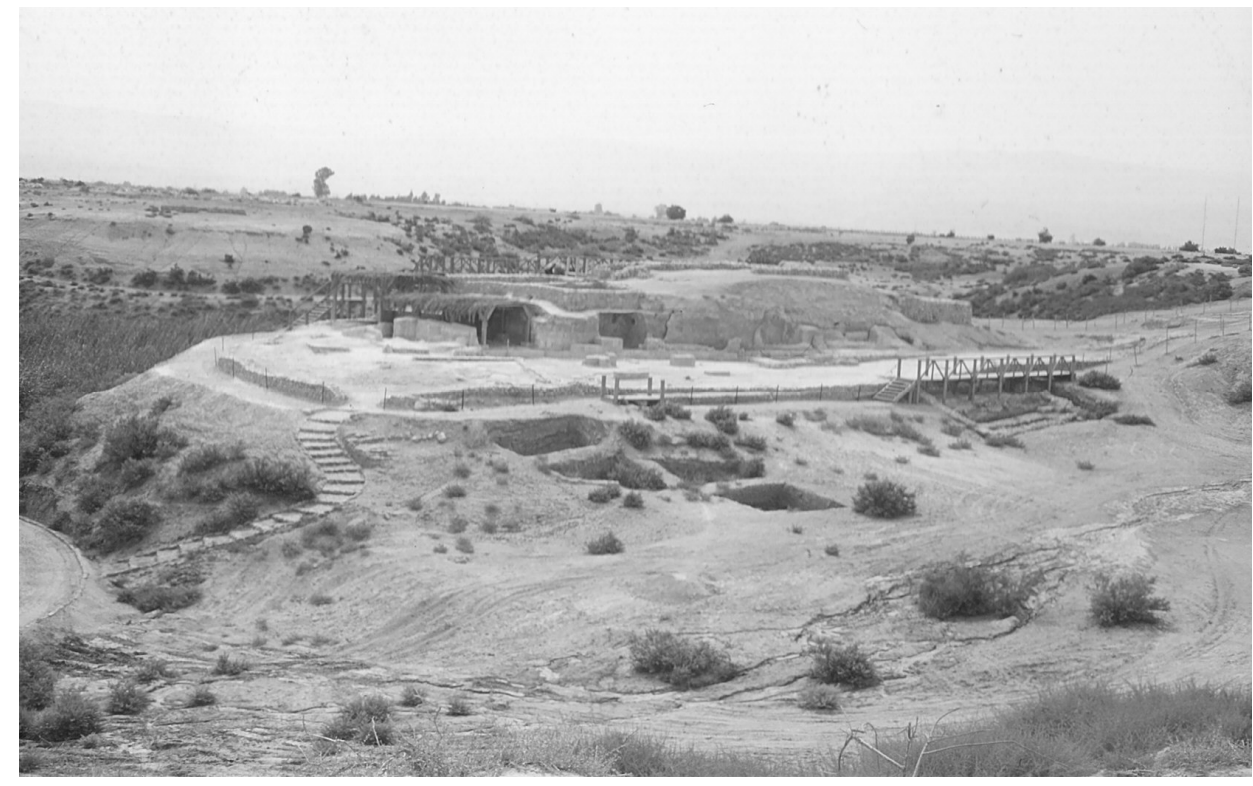

Figure 8. The Cave Cell on the eastern of Elijah's Hill (Waheeb 2000)

\section{John the Baptist church area:}

Some $300 \mathrm{~m}$ east and $70 \mathrm{~m}$ north of the present course of the Jordan river, archaeologists and architects have uncovered the remains of memorial churches in an area they are calling the "John the Baptist church area". Remnants of structures within this area are: a pillared hall (the first church); the lower basilica (the second church); a basilica (the third church); a room south of the basilica (mosaic pavement); staircase; four piers; a chapel (the fourth church); and later structures (later Islamic structures).

All were built on the spot where believers located John's baptism of Jesus. Over the centuries, this series of churches was destroyed, at least in part, by floods and/or earthquakes; but they were rebuilt because believers wished to have a memorial at the place where they were convinced the baptism of Jesus took place (Waheeb 2001: 600).

The structures date between the fifth and $12^{\text {th }}$ centuries. Had they been constructed in a less precarious location, some would probably have survived.

A compression of the architectural remains with the historical texts cited above is enlightening: Theodosius refers to what was probably the pillared hall, Arculf mentions a structure carried on four piers and possibly the staircase, Willibald may be referring to the four piers and the presumed church above these piers, and Abbot Daniel probably mentions the chapel built on the ruins of the four piers.

\section{Site of Saint Mary of Egypt:}

The Site of Saint Mary of Egypt consists of the remains of two adjacent structures dating from the Byzantine and Ottoman periods. The site commemorates the former Egyptian prostitute's repentance and miraculous conversion at the Church of the Holy Sepulcher in Jerusalem in the fourth or fifth century. The story is told by Sophronius, the companion of John Moschus and later Patriarch of Jerusalem. According to Sophronius, the voice of the Virgin Mary told Mary of Egypt to cross the Jordan river in order to "find rest". She lived alone in this area east of the river for forty-seven years, fasting and praying. Before dying she was found by Zosima, a monk from a nearby monastery. Zosima prayed with her, listened to her story, and gave her Holy Communion shortly before she died. He buried her with the assistance of a lion (Waheeb, M. 2004).

\section{Conclusions}

There appears to be little doubt that the Wadi al-Kharrar can be associated with the Prophet Elijah's ascension to heaven. It was at the eastern end of the wadi that believers placed his departure from earth by means of "a chariot and horses of fire" as he "ascended in a whirlwind into heaven." The location fits well with the biblical narratives relating the crossing of the nearby Jordan by Joshua and the parting of the waters by both Elijah and 
his successor Elisha. This could also be the location of Wadi Cherith, to which Elijah fled form Ahab, and where he was fed by ravens in the morning and the evening.

John the Baptist and his connection to Elijah fit equally well in the region of Wadi al-Kharrar. Believers saw the promise of Elijah's return fulfilled in the coming of John. It was here, at "Bethany beyond the Jordan," that John lived during the time of his ministry. Disciples, who were associated with his baptizing and preaching activities, would have been his companions. The place was convenient as it was close to Bethabara, "the house of the crossing", one of the places where travelers would have crossed the Jordan on their way east or west.

It was to "Bethany beyond the Jordan" that Jesus came to be baptized by John. Believers, as archeological investigations have shown, commemorated the place of Jesus' baptism by a series of churches and a monastery that, according to the "Piacenza pilgrim", contained two guest houses. Moreover, following John's death, Jesus retired to this area when the religious authorities in Jerusalem began to put pressure on him.

In Conclusion, the biblical texts, early pilgrims' reports, the Madaba mosaic map, and recent archeological work ALL AGREE in locating the place of the activities of John the Baptist and the baptism of Jesus east of the Jordan River at Bethany beyond the Jordan, near Elijah's Hill.

\section{References}

Abel R. (1932). Exploration du sud-est de la Vallee du Jordain, RB, 43 (Suie et fin), 237-263.

Allita, E., \& Piccirillo, M. (1999). Madaba Map Centenary 1897-1997. Jerusalem.

Feedarlan, L. (1902-1904). Recherches Sur Les Laures et Monasteres de Ia Plaine de Jordain, du desert de Jerusalem, Ia Terre Sante, 19(1902), 129-132.

Mkhjian. R., \& Kanellopoulos, C. (2003). John the Baptist Church Area: Architectural Evidence. ADAJ. 47, 9-18.

Moschos, John. (1992). The Spiritual Meadow, Translated by John Wortley. Christian Publications, USA.

Piccirillo, M. (1987). The Jerusalem-Esbus Road and its sanctuaries in Trans-Jordan, 165-172. Studies in the History and Archaeology of Jordan 31(1st ed.). A. Hadidi. Amman: Department of Antiquities, 11-1919.

Piccirillo, M. (1996). La Strada Romana Esbus-Livias, Liber Annus, 46, 285-300.

Taylor, J. Christians and the Holy Places. The Myth of Jewish-Christian Origins, Oxford: Clarendon.

Waheeb, M. (1997). Report on the Excavations at Wadi al-Kafrein Southern Ghor (Al Aghwar). ADAJ, 41, 463-468.

Waheeb, M. (1998). New discoveries near the baptism site, Occident and Orient, 3(1), 19-20.

Waheeb, M. (1998). Wadi al-Kharrar al-Maghtas, AJA, 102(3), 601.

Waheeb, M. (1998). Wadi al-Kharrar Archaeological Project, $A D A J, 43$, 635-638.

Waheeb, M. (1998). Wadi al-Kharrar, AJA, 102(3), 106.

Waheeb, M. (1999). Wadi al-Kharrar Archaeological Project. The Monastery, ADAJ, XLIII, 549-557.

Waheeb, M. (2001). Archaeological Excavations at the Baptism site Bethany Beyond the Jordan. Bible and Spade, 14(2), 43-53.

Waheeb, M. (2001). Wadi al-Kharrar Archaeological Project. The Survey Studies in the History and Archaeology of Jordan, VII, 591-601.

Waheeb, M. (2002). Cultural Resources Management of Bethany Beyond the Jordan, Seventh International Forum UNESCO - University and Heritage Conference 6-20 December, Yarmouk University in Collaboration with Hashemite University, Jordan (forthcoming).

Waheeb, M. (2002). Wadi al-Kharrar. AJA, 106, 445-449.

Waheeb, M. (2004). The Discovery of Site of St. Mary of Egypt. Amman, al- khat al- arabi press.

Wilken, R. (1992). The Land Called Holy: Palestine in Christian History and Thought. New Haven, CT: Yale University.

Wilkinson, J. (1976). Christian Pilgrims in Jerusalem during the Byzantine Period. Palestine Exploration Quarterly, 108, 75-101.

Wilkinson, J. (1977). Jerusalem Pilgrims Before the Crusaders. Aris and Philips Publishers, England. 
Wilkinson, J. (1981). Egerias Travels to the Holy Land. Jerusalem.

Wilkinson, J. (2002). Jerusalem Pilgrims Before the Crusaders (2 ${ }^{\text {nd }}$ ed.). Aris and Philips Publishers, England.

Wilson. C.W. (et). (1895). The Pilgrimage of the Russian Abbot Daniel in the Holy Land. 1106-1107 AD. Palestine Pilgrims' Text Society 4. London. Palestine Exploration Fund.

Note

Note 1. Wilken II 118: "The potsherds on the slopes and at the foot of the hill belong to the time of Christ. Opposite the southern slope are to be found the entrances of two rock-graves, almost filled up with debris... and within the grave-chambers, as well as some bones, three skulls which immediately crumbled. In one of the chambers are two oil-lamps and three coins belonging to the reign of Herod Agrippa... we opened up three more rock-graves there. They contained nothing, it is true but their arrangement suggests that they belonged to the time of Christ. 